\title{
Studies on Physico-Chemical Properties of Value Added Guava Toffee during Storage (Psidium guajava $\mathbf{L}$.)
}

\author{
Atul Praveen Panna ${ }^{1}$ and Ritu Rani Minz ${ }^{2} *$ \\ ${ }^{1}$ Department of Fruit Science, SHIATS Allahabaad (UP) 211007, India \\ ${ }^{2}$ Department of Horticulture, College of Agriculture, IGKV, Raipur (C.G.) 492012, India \\ *Corresponding author
}

\section{A B S T R A C T}

\section{Keywords}

Cardamom powder, Vanilla, citric acid, Pineapple flavours

Article Info

Accepted:

18 May 2020

Available Online:

10 June 2020
The present investigation entitled 'Studies on physico-chemical properties of value added Guava toffee during storage (Psidium guajava L.)' was conducted in the laboratory of the Department of Horticulture, during the year 2014-2015 to evaluate the two pre-treatment (blanching and sulphitation) and different flavours (Cardamom powder, Vanilla, citric acid, Pineapple). Guava toffee stored in ambient temperature. The experiment was laid out in the $2 \times 4$ factorial CRD with 10 treatments and 3 replications. The treatment $\mathrm{T}_{9}$ Sulphitation + Pulp extraction + preparation of guava toffee with sugar + chocolate + Pineapple flavour was found superior in respect of all the parameters viz. T.S.S. (12.66 ${ }^{0}$ Brix), Ascorbic acid $(47.45 \mathrm{mg} / 100 \mathrm{~g})$ and organoleptic quality was also found superior in this treatment.

\section{Introduction}

Guava (Psidium guajava L.) is one of the most important subtropical fruit crops. It belongs to family Myrtaceae. Guava is a native of tropical America perhaps from Mexico and Peru. It is widely distributed all over the equatorial regions of the tropical and subtropical climate.

The area under guava is about 219.7 million hectare producing 2571.5 Million tones of fruit and productivity 11.70 metric tons /ha. Uttar Pradesh is the leading state in guava production followed by Maharashtra and Bihar. Uttar Pradesh is a largest state in India and the largest total cultivation area is 39.9 million hectare, production 486.7 million tones and productivity 12.20 metric tones /ha.

The popular varieties of guava grown in India are Sardar, Allahabad Safeda, Lalit, Pant Prabhat, Dhareedar, Arka Mridula, Khaja (Bengal Safeda), Chittidar, Harija etc. Hybrid 
varieties like Arka Amulya, Safed Jam and Kohir Safeda were also developed for cultivation (NHB Database 2010). Guava is considered to be one of the exquisite, nutritionally valuable and remunerative crops, bears heavy crop every year and gives good economic returns. This has prompted several farmers to take up guava orcharding on a commercial scale. In recent years, guava is gaining popularity in the international trade due to its nutritional value and processed products. Guava is a rich source of Vitamins and minerals. Nutritive value of guava per 100 gm. Vitamin A, 250 I.U. and Vitamin B (Thiamine), $0.7 \mathrm{mg}$. Niacin $1.2 \mathrm{mg}$. Vitamin C, 302 mg. Calcium, 30 mg. Phosphorus, 29 mg. Carbohydrates, $17.1 \mathrm{gm}$. Protein, $1.0 \mathrm{gm}$. Calories. The ripe fruit is usually eaten as dessert. It can also be utilized in many ways for making jellies, jam, paste, juice, baby foods, syrup, wine and other processed products.

Guava is the most important fruit in India after mango, banana and citrus fruits, and has a high nutritive value. Guava fruit is rich source of ascorbic acid and pectin. Guava fruit are used for making jam, jelly, nectar, wine, toffee, sharbat, juice, sauce, flakes, RTS beverage, dehydrated slice, cheese and various culinary purposes. Value-added food products are raw or pre-processed commodities whose value has been increased through the addition of ingredients or processes that make them more nutritive and attractive to the buyer and more readily usable by the consumer. It is a production strategy driven by customer needs and perceptions.

Guava fruits may be utilized to make products like jam, jelly, cheese, juice. Canned segment, nectar, RTS beverage dehydrated slice, flakes, Toffee, sauce and guava lather, baby food puree, etc. However, the most commercially use of guava is for jelly preparation. There is great demand of red fleshed guava in world market for juice making dehydrated guava juice is also a good source of vitamin C. Fruit toffees are made from pulpy fruits like banana, mango, jackfruit, guava etc. Fruits are grown seasonally and are perishable in nature. Fruit preservation techniques enable the mankind to enjoy fruits even during offseason and fruit toffees one such product. Fruit toffees are highly nutritious products compared to sugar boiled confectionaries.

\section{Materials and Methods}

The present investigation entitled 'Studies on physico-chemical properties of value added Guava toffee during storage (Psidium guajava L.)' was laid out in the Post- Harvest Laboratory of Horticulture Department, Sam Higginbottom Institute of Agriculture, Technology and Sciences, Allahabad during the year 2014-2015, to find out the effect of pre- treatments on the quality of Guava Toffee at ambient temperature. The experiment was laid out in the $2 \times 4$ factorial CRD with 10 treatments and 3 replications.

Table.a Material used for toffee preparation

\begin{tabular}{|l|l|}
\hline Materials & \multicolumn{1}{|c|}{ Quantity } \\
\hline Guava pulp & $500 \mathrm{~g}$ \\
\hline Sugar & $750 \mathrm{~g} / \mathrm{kg}$ pulp \\
\hline Chocolate powder & $100 \mathrm{~g} / \mathrm{kg}$ pulp \\
\hline Butter & $25 \mathrm{~g} / \mathrm{kg}$ pulp \\
\hline Milk powder & $20 \mathrm{~g} / \mathrm{kg}$ pulp \\
\hline Flavours & $\begin{array}{l}\text { Cardamom powder, Vanilla, } \\
\text { citric acid, Pineapple, }\end{array}$ \\
\hline Preservative & MS or Sodium benzoate \\
\hline
\end{tabular}

\section{Preparation of guava pulp}

Selection of fruits (Ripe and firm) and Washing and cutting into pieces and Mixing with water $(200 \mathrm{ml})$ Passing through pulper or boiling in water (30 minute) and Straining of pulp and cooling (30 minute) and Preparation for guava toffee. 


\section{Process for toffee preparation}

Take guava pulp in a container and add 750 $\mathrm{g} / \mathrm{kg}$ pulp sugar and boil it at $70{ }^{0} \mathrm{Brix}$, followed by addition of $100 \mathrm{~g} / \mathrm{kg}$ pulp of chocolate powder slowly stirring all mixture with the help of spatula up to $82-85^{0}$ Brix for 10-15 minutes.

Add $20 \mathrm{~g} / \mathrm{kg}$ pulp milk powder and followed by addition of $25 \mathrm{~g}$ butter with treatment wise (Cardamom powder Vanilla, citric acid, Pineapple) for the $500 \mathrm{~g}$ prepared mixture. Take all the mixture in a tray and spread it and leave it for 8 to 10 hours. After the proper cooling round shaped pieces measuring $(5 \mathrm{~g})$ with uniform size where prepared and wrapped with butter paper and kept it at ambient temperature storage.

Factor A

1. Blanching

2. Sulphitation

\section{Factor B:}

\section{Value addition}

1. No flavor

2. Cardamom flavor

3. Vanilla flavor

4. citric acid flavor

5. Pineapple flavor

Table.b Treatment details

\begin{tabular}{|c|c|}
\hline Treatments & Treatment details \\
\hline $\mathbf{T}_{\mathbf{0}}$ & $\begin{array}{l}\text { Blanching of fresh guava slices + pulp extraction + preparation of guava toffee } \\
\text { with sugar + No flavour }\end{array}$ \\
\hline $\mathbf{T}_{1}$ & $\begin{array}{l}\text { Blanching of fresh guava slices + pulp extraction + preparation of guava toffee } \\
\text { with sugar + chocolate + Cardamom flavour }\end{array}$ \\
\hline $\mathbf{T}_{2}$ & $\begin{array}{c}\text { Blanching of fresh guava slices + pulp extraction + preparation of guava toffee } \\
\text { with sugar + chocolate }+ \text { Vanilla flavour }\end{array}$ \\
\hline $\mathbf{T}_{3}$ & $\begin{array}{l}\text { Blanching of fresh guava slices + pulp extraction + preparation of guava toffee } \\
\text { with sugar + chocolate + citric acid flavour }\end{array}$ \\
\hline $\mathbf{T}_{4}$ & $\begin{array}{l}\text { Blanching of fresh guava slices + pulp extraction + preparation of guava toffee } \\
\text { with sugar + chocolate + Pineapple flavour }\end{array}$ \\
\hline $\mathbf{T}_{5}$ & Sulphitation + pulp extraction + prepare of guava toffee with sugar + No flavour \\
\hline $\mathbf{T}_{6}$ & $\begin{array}{c}\text { Sulphitation + pulp extraction }+ \text { preparation of guava toffee with sugar +chocolate } \\
+ \text { + Cardamom flavour }\end{array}$ \\
\hline $\mathbf{T}_{7}$ & $\begin{aligned} \text { Sulphitation }+ \text { pulp extraction }+ & \text { preparation of guava toffee with sugar }+ \text { chocolate } \\
& + \text { Vanilla flavour }\end{aligned}$ \\
\hline $\mathbf{T}_{8}$ & $\begin{array}{c}\text { Sulphitation }+ \text { pulp extraction }+ \text { preparation of guava toffee with sugar }+ \text { chocolate } \\
+ \text { + citric acid flavour }\end{array}$ \\
\hline $\mathbf{T}_{9}$ & $\begin{array}{c}\text { Sulphitation + pulp extraction + preparation of guava toffee with sugar + chocolate } \\
+ \text { Pineapple flavour }\end{array}$ \\
\hline
\end{tabular}




\section{Results and Discussion}

The data presented in table no. 1 shows the mean sensory scores for guava toffee preparation with different treatments. TSS showed an increasing trend in all the treatments at different intervals of storage.

The maximum TSS $\left(12.66{ }^{0}\right.$ Brix $)$ was recorded in $\mathrm{T}_{9}$ Sulphitation + pulp extraction + preparation of guava toffee with sugar + chocolate + Pineapple flavor followed by $\left(12.65{ }^{0}\right.$ Brix $)$ in $\mathrm{T}_{7}$ Sulphitation + pulp extraction + preparation of guava toffee with sugar + vanilla + chocolate + Vanilla flavour and minimum $\left(11.77{ }^{0}\right.$ Brix $)$ was with $\mathrm{T}_{0}$ Blanching of fresh guava slices treatment + pulp extraction + prepare of guava toffee with sugar + No flavour.

An increasing trend in the $\mathrm{pH}$ of value added guava toffee was recorded. The minimum (4.236) was recorded in $\mathrm{T}_{7}$ Sulphitation + pulp extraction + prepare of guava toffee with sugar + chocolate + Vanilla flavour followed by (4.359) in $\mathrm{T}_{4}$ Blanching of fresh guava slices treatment + pulp extraction + prepare of guava toffee with sugar + chocolate + Pineapple flavor and maximum $\mathrm{pH}$ (4.832) was with $\mathrm{T}_{0}$ Blanching of fresh guava slices treatment + pulp extraction + prepare of guava toffee with sugar + No flavour.

A decreasing trend in the acidity of value added guava toffee was recorded till (90 days) of storage. The maximum (0.497) was recorded in $\mathrm{T}_{4}$ blanching of fresh guava slices treatment + pulp extraction + prepare of guava toffee with sugar + chocolate + Pineapple flavor followed by $(0.484)$ in $\mathrm{T}_{9}$ Sulphitation + pulp extraction + prepare of guava toffee with sugar + chocolate + Pineapple flavor and minimum acidity (0.425) was with $\mathrm{T}_{5}$ Sulphitation + pulp extraction + prepare of guava toffee with sugar + no flavour.
Ascorbic acid showed a decreasing trend in all the treatments during storage. The maximum ascorbic acid (47.45) was recorded in $\mathrm{T}_{9}$ Sulphitation + pulp extraction + prepare of guava toffee with sugar + chocolate + Pineapple flavor followed by (37.11) in $\mathrm{T}_{4}$ Blanching of fresh guava slices treatment + pulp extraction + prepare of guava toffee with sugar + chocolate + Pineapple flavor and minimum (25.21) was with $T_{5}$ Sulphitation + pulp extraction + prepare of guava toffee with sugar + No flavor.

Reducing sugar showed a decreasing trend in all the treatments at different intervals of storage. The maximum reducing sugar (3.29\%) was recorded in $\mathrm{T}_{0}$ Blanching of fresh guava slices treatment + pulp extraction + preparation of guava toffee with sugar + No flavour and minimum (3.10\%) was with $\mathrm{T}_{9}$ Sulphitation + pulp extraction + preparation of guava toffee with sugar + chocolate + Pineapple flavor.

Non-reducing sugar showed a decreasing trend in all the treatments during storage. The maximum non reducing sugar $(5.76 \%)$ was recorded in $\mathrm{T}_{9}$ Sulphitation + pulp extraction + preparation of guava toffee with sugar + chocolate + Pineapple flavor and minimum (5.28\%) was with $\mathrm{T}_{0}$ Blanching of fresh guava slices treatment + pulp extraction + preparation of guava toffee with sugar + No flavor.

The maximum overall acceptability score (7.91) was recorded in $T_{9}$ Sulphitation + pulp extraction + preparation of guava toffee with sugar + chocolate + Pineapple flavor followed by (7.58) in $\mathrm{T}_{4}$ blanching of fresh guava slices treatment + pulp extraction + prepare of guava toffee with sugar + chocolate + Pineapple flavor and minimum (6.58) was with $\mathrm{T}_{0}$ Blanching of fresh guava slices treatment+ pulp extraction + prepare of guava toffee with sugar + No flavour. 
Table.1 Effect of different treatments on physic- chemical property of value added Guava Toffee during storage

\begin{tabular}{|c|c|c|c|c|c|c|c|c|}
\hline $\begin{array}{l}\text { Treat } \\
\text { ment } \\
\text { No. }\end{array}$ & Treatment & $\begin{array}{l}\text { Total } \\
\text { soluble } \\
\text { solids } \\
\left({ }^{\circ} \text { Brix }\right)\end{array}$ & pH & Acidity & $\begin{array}{l}\text { Ascorbic } \\
\text { acid } \\
(\mathbf{m g} / \mathbf{1 0 0 g})\end{array}$ & $\begin{array}{l}\text { Reducing } \\
\text { sugar }\end{array}$ & $\begin{array}{l}\text { Non } \\
\text { reducing } \\
\text { sugar }\end{array}$ & $\begin{array}{l}\text { Overall } \\
\text { accepta } \\
\text { bility }\end{array}$ \\
\hline $\mathbf{T}_{\mathbf{0}}$ & $\begin{array}{l}\text { Blanching of fresh guava slices treatment }+ \text { pulp extraction } \\
+ \text { preparation of guava toffee with sugar }+ \text { No flavour }\end{array}$ & 11.77 & 4.832 & 0.431 & 27.67 & 3.29 & 5.28 & 6.58 \\
\hline $\mathbf{T}_{1}$ & $\begin{array}{l}\text { Blanching of fresh guava slices treatment+ pulp extraction } \\
+ \text { preparation of guava toffee with sugar }+ \text { chocolate }+ \\
\text { Cardamom flavour }\end{array}$ & 12.47 & 4.596 & 0.449 & 35.44 & 3.20 & 5.55 & 7.03 \\
\hline $\mathbf{T}_{2}$ & $\begin{array}{l}\text { Blanching of fresh guava slices treatment }+ \text { pulp extraction } \\
+ \text { preparation of guava toffee with sugar }+ \text { chocolate }+ \\
\text { Vanilla flavour }\end{array}$ & 12.61 & 4.526 & 0.458 & 35.61 & 3.15 & 5.64 & 7.14 \\
\hline $\mathbf{T}_{3}$ & $\begin{array}{l}\text { Blanching of fresh guava slices treatment+ pulp extraction } \\
+ \text { preparation of guava toffee with sugar + vanilla } \\
+ \text { chocolate + citric acid flavour }\end{array}$ & 12.48 & 4.606 & 0.441 & 30.56 & 3.21 & 5.53 & 6.83 \\
\hline $\mathbf{T}_{4}$ & $\begin{array}{l}\text { Blanching of fresh guava slices treatment }+ \text { pulp extraction } \\
+ \text { preparation of guava toffee with sugar }+ \text { chocolate }+ \\
\text { Pineapple flavor }\end{array}$ & 12.64 & 4.359 & 0.497 & 37.11 & 3.13 & 5.69 & 7.58 \\
\hline $\mathbf{T}_{5}$ & $\begin{array}{l}\text { Sulphitation + pulp extraction + preparation of guava toffee } \\
\text { with sugar + No flavour }\end{array}$ & 11.94 & 4.821 & 0.425 & 25.21 & 3.27 & 5.34 & 6.69 \\
\hline $\mathbf{T}_{6}$ & $\begin{array}{l}\text { Sulphitation + pulp extraction + preparation of guava toffee } \\
\text { with sugar + chocolate + Cardamom flavour }\end{array}$ & 12.40 & 4.485 & 0.446 & 34.31 & 3.17 & 5.58 & 7.20 \\
\hline $\mathbf{T}_{7}$ & $\begin{array}{l}\text { Sulphitation + pulp extraction + preparation of guava toffee } \\
\text { with sugar + chocolate + Vanilla flavour }\end{array}$ & 12.65 & 4.455 & 0.447 & 36.23 & 3.19 & 5.70 & 7.25 \\
\hline $\mathbf{T}_{8}$ & $\begin{array}{l}\text { Sulphitation + pulp extraction + preparation of guava toffee } \\
\text { with sugar + chocolate }+ \text { citric acid flavour }\end{array}$ & 12.61 & 4.607 & 0.435 & 31.37 & 3.18 & 5.56 & 6.95 \\
\hline \multirow[t]{4}{*}{$\mathbf{T}_{9}$} & $\begin{array}{l}\text { Sulphitation + pulp extraction + preparation of guava toffee } \\
\text { with sugar + chocolate + Pineapple flavor }\end{array}$ & 12.66 & 4.236 & 0.484 & 47.45 & 3.10 & 5.76 & 7.91 \\
\hline & F- test & S & S & S & S & S & $\mathrm{S}$ & S \\
\hline & S. Ed. $( \pm)$ & 0.02 & 0.002 & 0.004 & 0.47 & 0.03 & 0.003 & 0.08 \\
\hline & C. D. $(P=0.05)$ & 0.04 & 0.004 & 0.007 & 0.97 & 0.07 & 0.005 & 0.09 \\
\hline
\end{tabular}


Similar findings have been reported by Nidhi et al., (2011) incorporation of guava in carrot cheese. Bhat and Singh (2014) in guava pulp.Vinod et al., (2012) in Allahabad Safeda + Cashew nut cheese.

Based on findings of the present experiment it may be concluded that treatment $\mathrm{T}_{9}$ Sulphitation + pulp extraction + preparation of guava toffee with sugar + chocolate + Pineapple flavor was found superior in respect of all the parameters viz. T.S.S. (12.66 ${ }^{0}$ Brix), Ascorbic acid $(47.45 \mathrm{mg} / 100 \mathrm{~g})$.

\section{References}

Bhat, F. M. and Singh, R. (2014). Preparation,
Quality Evaluation and Shelf Life Studies of Whey-Guava Beverage. World J. of Agri. Sci. 10 (3): 141-145.

NHB (2010). National Horticulture Board data base http://nhb.gov.in/ estimates.xls.

Nidhi, Prasad, R, Prasad, V.M. and Sheikh, S. (2011). Development of carrot cheese through value addition with guava, The Allahabad Farmer. Vol. LXVI, No. 2, 132-135.

Vinod Kumar, Devi Singh, Vijay Bahadur and V.M. Prasad (2012). Value Addition of Guava Cheese with Different Cultivars of Guava, M.Sc. Thesis, Dept. of Hort. SHIATS, Allahabad (U.P).

\section{How to cite this article:}

Atul Praveen Panna and Ritu Rani Minz. 2020. Studies on Physico-Chemical Properties of Value Added Guava Toffee during Storage (Psidium guajava L.). Int.J.Curr.Microbiol.App.Sci. 9(06): 1153-1157. doi: https://doi.org/10.20546/ijcmas.2020.906.143 